\title{
THE DAY HOSPITAL IN THE COMMUNITY
}

\section{J. Hattingh, Chief Nursing Officer, Cape Province}

\section{OPSOMMING}

Die rol van die verpleegster het verander en verander nog steeds, soos ook met die rol van die mediese praktisyn in die daghospitaal-sentrum gebeur. Hy word eerder as opvoeder en voorligter beskou, waar die primêre sorgverpleegkundige die persoon is wat aktief met die behandeling van pasiënte gemoeid is.

Met sy uitgebreide ontwikkeling van 'n distriksdiens bied die daghospitaal 'n omvattende gesondheidsdiens aan gemeenskappe, en Kaapland beskou die ontwikkeling sedert 1968 reeds as 'n voorsiening in die behoeftes van mense soos dit in die nuwe Gesondheidswet van 1977 uitgestippel is.

Fasiliteite in die gemeenskap bring mee dat daar minder pasiënte in hospitale opgeneem word, pasiënte kan as gevolg van die opvolgdiens vroeër ontslaan word. 'n Moeder is dus gou weer tuis en daar is geen verbreking van maatskaplike bande waardeur verwerping en depressie veroorsaak word nie.

T HE term Day Hospital is attached to centres where primary health care is rendered, not necessarily only during the day, but rather to a community who cannot readily reach other existing facilities. The first day hospital was opened in 1860 in Cape Town for this reason; it could then be seen as an extended arm of the hospital to the community. Numerous conditions are treated that do not need any hospitalisation or necessitate the direct attention of a medical practitioner.

Practising nurses are now equipped on a formal or inservice basis to occupy a role of "filler-in" of gaps in the absence of the specialist here, the medical practitioner or paramedical team member. This role of the nurse is now openly defined although it has been practised throughout the ages i.e. observing, diagnosing and treating people in the sphere of her ability and knowledge and within the scope of her field.

The new Health Act, Act 63 of 1977, refers to such centres as Community Health Centres and in the future the name "Day Hospital" may be changed to "Community Centre."

In an address to a group of nurse-leaders, the Director recently spelled out the aim of the Department of Hospital Services, C.P.A. for Health Year, i.e. that at least five community health centres will be built in the Cape Province during this year in communities where no hospital facilities exist.

The greater number of patients in these centres will be dealt with by nurse practitioners and only those persons who need more specialized attention will be referred to 
the medical practitioner. The nurse will always practise in close collaboration with the medical practitioner, but she will always remain nurse practitioner in her own right.

Where most of the Day Hospitals planned in the twenties are primarily sited in areas where large Black and Coloured population groups are concentrated, the aim of the future is to make a Health Service available to all people through Community Health Centres or Day Hospitals as they are known in the Cape Province at present.

The first hospital to which the term "Day Hospital" could be attached was built in 1860 in Burg Street, Cape Town for indigent patients unable to travel to the new Somerset Hospital in Mouille Point and it was at that time named the "Open Dispensary". The Day Hospital was therefore then seen as an extended arm of the hospital into the community.

The Community Health Service of today, however, is a modern trend in medical care, with the emphasis on care and community involvement. Health education is an integral part of community health and has the ultimate aim of active participation by the patient in his or her own health and that of their neighbours. The system was commenced during 1968 in the Cape Peninsula. In the Cape Province there are today Day Hospitals in existence in the country as well as in the cities.

These hospitals are built at strategic places where the need exists. There is, however, a vast difference between these two groups i.e. the Peninsula Day Hospitals (cities) and the country Day Hospitals.

\section{THE CAPE PENINSULA DAY HOSPITALS}

There are 16 Day Hospitals and six District Rooms in existence in this organisation. The primary health care rendered by nurses in these centres cannot be compared with that rendered by nurses in the country because -

- these centres are specially designed for this service of Primary Health Care and offer a holistic service;

- the availability of sophisticated apparatus and the technicians to maintain this in working order, e.g. $\mathrm{X}$-ray facilities, apparatus for physiotherapy and at some hospitals equipment for minor surgical procedures and laboratory facilities;

- the multi-disciplinary team with specialized training is based at the day hospitals or within easy reach for referral purposes.

The team will differ according to the specific needs of the patients. Members of the following disciplines are available:

\section{Physiotherapy \\ Social Welfare \\ Pharmacology \\ Radiography \\ Nursing: Basic}

\section{Medicine}

Medical practitioners (full and part time) are designated to the Day Hospitils. There are regular specialist clinics, e.g. cardiac, orthopaedic, paediatric, obstetric, psychiatric clinics held either on a weekly basis or according to needs and priorities.

Nursing specialised in Paediatrics, Orthopaedics, Obstetrics, Primary Health, Psychiatric care etc.

With all the members of these disciplines available, the Primary Health Care rendered by nurses therefore differs to a certain extent from the care by nurses in the country.

\section{Nursing}

The basically trained nurse renders primary health care according to the needs in a specific area.

Specialised post-registration nurses such as the paediatric nurse, the purse with the Diploma in Advanced Midwifery and Neonatal Care are based at these centres and relieve the work of the overloaded paediatricians and obstetricians.

The post-registration midwife renders a comprehensive midwifery service from these centres.

\section{THE ROLE OF THE DAY HOSPITAL IN THE CAPE PENINSULA COMMUNITIES}

In co-ordination with all the referral hospitals a comprehensive health service is rendered. Screening and, depending on facilities and personnel, certain conditions are treated at the Day Hospital. When necessary all specialist in-patient health service given are referred to the various hospitals; the patients are in due course discharged to the community and followed up by nurses based at the Day Hospitals. There is thus a two-way communication system, and this means that a comprehensive community service is rendered.

At the moment only nursing procedures are carried out in this district service, because the necessary medical and paramedical care are available. It is not a case of home nursing but follow-up nursing in accordance with prescribed treatment.

This community service provides facilities for the prescribed training in Preventative and Promotive Health as all students and pupils are circulated through these hospitals for the prescribed time. This promotes the confidence of the nurse in her own abilities from her student life onwards. She first assists in the nursing with trained personnel, but as soon as she is trained is expected to take full responsibility for her own decisions and actions. 
Physiotherapists also render a community service and continue the physiotherapy at the homes of patients.

The obstetrical units attached to the Day Hospitals provide a total midwifery service for all normal pregnancies.

The midwife does at least one antenatal visit, the delivery preferably being done at the unit and the care during the puerperium carried out at home. The mothers are discharged from 6 - 24 hours after delivery. The midwife is in the unique position to evaluate the family in its totality and being in close contact can do the necessary referrals where necessary as well as promoting health through guidance.

\section{In-Service Training}

Apart from formal basic and post-basic training, there is a programme of continuing education for the personnel of these centres. In the Cape Province a course is offered on an in-service basis in history-taking.

There is also a course offered on the same basis for primary health care. Not only nurses from the Day Hospitals, but those from the rural areas are seconded to the Day Hospitals for this course. Thereafter they render valuable service at out-patient departments as well as Day Hospitals and community health centres in the country.

The nurse specialising in paediatrics and equipped with the advanced course in this field handles paediatric problems on her own, on short or often long-distance cover of a medical practitioner or paediatrician.

Health Education is an integral part of all the other services at Day Hospitals. In-service training programmes for all categories - paramedical, doctors, nursing - have been developed. The courses are structured according to needs and priorities and are flexible. Audiovisual aids are also produced for purposes of health education and are distributed to all Day Hospitals.

The Day Hospitals are built in the suburbs where the population of the groups in need of care is dense, the socio-economic needs demand it, and transport is not always available. This immediately results in availability of a service, attendance and not negligence, early diagnosis, treatment and prevention of serious complications.

\section{A COUNTRY DAY HOSPITAL}

\section{The following factors are important:}

The principles as they apply to these services differ only to the extent that country centres are maintained in the majority of cases by nurses and the minimum of doctors or under long-distance coverage of a doctor. The building used as a centre is what is available and not what is needed. The nurses have to improvise a great deal:

* there is a memorandum with guidelines for the nursing personnel

* a policy regarding the procedures to be adopted

* short notes on commonly recurring illnesses.

Selection of personnel calls for a sound basic education, adequate previous experience, intelligence and above all an 'absence of the resistance-to-change factor'.
In the country Day Hospital nurses attend to up to $89 \%$ of patients against $11 \%$ seen by doctors. In the cities the ratio is $48 \%$ by doctors, $52 \%$ by nurses. This, however, varies.

The policy of the Cape Provincial Administration is to build these centres in communities which are 50 kilometres or further away from available health services.

\section{THE EFFECT OF THIS APPROACH ON PRIMARY HEALTH CARE IN THE PAST AND AT PRESENT Paediatrics}

There has been a dramatic decline in the infant mortality rate, while the admission rate to paediatric wards has dropped and continues to decline.

Continuous maternal and child care and health education in respect of feeding problems, have resulted in complications such as Kwashiorkor becoming a rarity.

There are no long queues at the clinics waiting to "see the doctor".

The afternoons are devoted to special clinics, e.g. for: chronic heart and chest conditions, asthma, antenatal patients, psychiatric conditions, postnatal examinations, maternal and child care, health education, diabetic patients, obese patients and persons suffering from malnutrition.

The Hospital admission rate is kept down by a thorough follow-up system, especially for long-term conditions such as: chronic heart disease, chronic chest disease, diabetes and epilepsy.

\section{Orthopaedics}

All orthpaedic patients are regularly followed up by a registered nurse holding, if possible, the Diploma in Orthopaedic Nursing.

There is follow-up of patients with fractures who are still in plaster casts, a home service is rendered, and there is communication and co-ordination with other nurses in the community health field in areas where it exists.

\section{The Patients}

The patients appreciate the system once they have gained confidence in a nurse and they have learned that they attend the clinic for a service and not necessarily to "see a doctor".

\section{The Personnel}

For all team members the system means job satisfaction. There is a greater awareness of the field of the other disciplines, more respect for one another, more co-ordination and co-operation.

There is recognition of the services rendered by other authorities and both co-ordination and co-operation with them.

\section{Statistics of Attendance at Day Hospitals}

During 1977, 6535977 out-patients were treated in comparison with 52:278 in-patients at Provincial Hospitals in the Cape Province.

The cost in an ordinary Provincial Hospital per patient per day has risen between 1971 - 1977 from R16,17 to $\mathrm{R} 33,00$ to maintain a patient. The cost in a teaching hospital has risen from $\mathrm{R} 18,34$ to $\mathrm{R} 48,67$ for the same period. The following statistics show the contribution of the nurse in her extended role at a few Day Hospitals in the Cape Province during 1978. 


\begin{tabular}{|c|c|c|c|c|c|c|}
\hline Year & Day Hospital & $\begin{array}{l}\text { Patients } \\
\text { attended } \\
\text { to by } R / N\end{array}$ & $\%$ & $\begin{array}{l}\text { Patients } \\
\text { attended } \\
\text { to by M.O. }\end{array}$ & $\%$ & $\begin{array}{l}\text { Total } \\
\text { attendance } \\
\text { for } 1 \text { year }\end{array}$ \\
\hline 1978 & $\begin{array}{l}\text { Kwazakele - old } \\
\text { (1 year) }\end{array}$ & 71523 & 74,03 & 8403 & 26 & 97926 \\
\hline 1978 & Cradock, since 1967 & 67153 & 87 & 9980 & 13 & 77133 \\
\hline 1978 & Adelaide (country) & 24924 & 89 & 2995 & 11 & 27919 \\
\hline 1978 & $\begin{array}{l}\text { D.H.O. - Cape } \\
\text { Peninsula }\end{array}$ & 614500 & 42 & 824065 & 58 & 1438565 \\
\hline
\end{tabular}

\section{CONCLUSION}

The role of the nurse has changed and still is changing: so, likewise, has the role of the medical practitioner in these centres changed for he is seen more in the role of educator and guide. It is the primary health care nurse who is the person actively involved in treating patients.

The Day Hospitals with their extended development of a district service provide a comprehensive health service to communities, and the Cape Province sees this development since 1968 as already implementing the needs of people as spelled out in the new Health Act of 1977.
With facilities in the community, fewer patients are treated and admitted to hospitals; patients can be discharged earlier because of the follow-up service. A mother is therefore soon back home and social ties are not broken which could lead to rejection and depression.

This promotes community participation because the family must now participate in the care of the patient during the period of rehabilitation in the community.

\section{RFFERENCES}

1. A memorandum compiled by Dr. J. Wessels for the Planning of Day Hospitals in the Eastern Cape and Barder Regions. August - September 1975

2. Annual ReporI, Director of Hospilal Services, C.P.A. 1977

3. Annual Reporls of Day Hospitals Organisation, Peninsula, 1977.

4. Information from the Principal Matron of the Day Hospitals Organisation. 5. Information from Opening Speech by Dr. Kolze to Matrons and Principals in the Cape
Province, March 1979 . 